\title{
PENGARUH PENGEMBANGAN KARIR DAN KONFLIK TERHADAP PRODUKTIFITAS KERJA PADA BADAN PENGELOLA KEUANGAN, PENDAPATAN DAN ASET DAERAH KABUPATEN KARO
}

\author{
Dearma Sariani Sinaga \\ Universitas Darma Agung \\ dearmasinaga2@gmail.com
}

\section{Julhendri Sinaga}

Institut Sains dan Teknologi TD. Pardede

julhenrisinaga07@gmail.com

\section{Frisderesia Sinaga}

Universitas Darma Agung

frisderesiasinaga@gmail.com

\begin{abstract}
The purpose of the research is to see if "The Career-Influence Development and Conflict Effect The Work Productivity in Financial Management Revenue and Expenditure Asset of Karo Regency." The sample in this study is 41 people ". Data collection techniques using questionnaires. From the results of the linear regression multiple test that a partial value is known to be count $x 1$ (7.780 > T.table $=1.682$ meaning there is a career-development influence on work productivity. Count $x 2(3.462)>$ T.table $=1,682$ meaning there is the impact of conflict on work productivity. There are simultaneously significant effects of career development and conflict on career development. This is proved that partial testing (test-f) is known by Fcount $>$ Ftable and sig-p value 0.05. Adjusted $R$ square value: 0.782 means that the overall impact of career development and conflict of the work productivity is $78.2 \%$. The most influential variable in occupational productivity is career development of 67\%. The conclusion of this research is that there is a career-development effect on work productivity, there is a conflict on work productivity, and there is a career-development and conflict on work productivity
\end{abstract}

Keywords Career Development, Conflict and Work Productivity

\section{PENDAHULUAN}

Pengembangan karir yang diinginkan oleh seseorang harus didukung dengan pencapaian hasil kerja dimana seseorang dengan kebebasan berkerja untuk meraih karir dimasa yang akan datang. Target sasaran yang dengan jelas harus diraih dengan menggunakan ilmu pengetahuan yang diperoleh melalui pendidikan formal dan nonformal. Karir yang dicapai merupakan usaha dengan penuh pertanggungjawaban atas beban kerja yang harus diselesaikan tanpa hambatan. Karir yang baik dapat dicapai jika seorang pekerja bisa melakukan perkerjaannya 
dengan baik dan melakukan terobosan kearah yang lebih baik baik dari hasil pekerjaan yang dilakukan sebelumnya. Didalam meningkatkan karir terdapat beberapa konfik yang harus dihadapi dengan bijaksana sehingga konflik yang terjadi dapat diselesaikan dengan baik dan tepat sasaran. Sebagian orang suka menghindari konfik dalam bekerja sehingga menimbulkan kejenuhan dalam bekerja. Konfil bukan hal yang negative jika dipandang dari sudut pandang yang positif, tetapi konfil dapat membawa perubahan kearah yang lebih baik lagi. Dengan adanya konfik pada tempat kerja itu membuktikan setiap pekerja yang ada disana bersemangat untuk menyelesaikan pekerjaan dengan baik. Konfik bisa menambah semangat para pekerja dalam bekerja, pekerja dapat menunjukan sisi kompeten dalam dunia pekerjaan yang digelutinya. Konfil dari segi positif merupakan persaingan yang sehat antar pengawai sehingga para pengawai berlomba lomba utuk menunjukan produktifitasnya dalam bekerja yang berdampak pada peningkatan karir para pegawai kearah yang positif. Jika produktifitas pegawai meningkat otomatis target yang ditetapkan dapat tercapai secara maksimum.

Pada kantor Badan Pengelolaan Keuangan, Pendapatan dan Aset Daerah Kabupaten Karo dengan banyak pengawai melakukan pengembangan karir sesuai dengan jenjang yang harus dilalui. Pengembangan karir akan diraih setelah setiap pegawai melewati tahapan-tahapan yang telah ditetapkan oleh pemerintah. Namun dalam meraih jenjang karir atau dalam melaksanakan pekerjaan sering juga mengalami konflik apalagi dalam suatu ruangan kerja dengan karakter dan selisih pendapat sering dialami. Konflik dalam tempat kerja sering terjadi walau tanpa disengaja bahwa akan menganggu produktifitas kerja. Dari uraian diatas maka penulis tertarik meneliti dengan judul "Pengaruh Pengembangan Karir dan Konflik Terhadap Produktifitas Kerja Pada Badan Pengelolaan Keuangan, Pendapatan dan Aset Daerah Kabupaten Karo.

\section{LANDASAN TEORI}

Karir adalah sebuah kata dari Bahasa Belanda; carriere adalah perkembangan dan kemajuan dalam pekerjaan seseorang. Menurut Sedarmayanti. (2015:103) karir adalah pola aktivitas dan pengalaman yang terkait dengan pekerjaan (misalnya, posisi jabatan, tugas-tugas dalam jabatan, keputusan, dan penafsiran subyektif tentang peristiwa-peristiwa yang terkait dengan pekerjaan) sepanjang kehidupan pekerjaan seseorang. Di mana dalam pengembangan karir mengarah pada perbaikan atau peningkatan pribadi yang diusahakan oleh individu maupun organisasi untuk memilih tujuan dan jalur karir untuk mencapai tujuan tersebut. Pengembangan karir adalah suatu kondisi dalam pengembangan potensi pegawai untuk menduduki jabatan yang lebih tinggi demi mewujudkan rencana karir dimasa yang akan datang.

Konflik adalah sebuah pertarungan dan benturan, perdulatan, pertengkaran kepentingan-kepentingan, opini-opini atau tujuan-tujuan, pergulatan mental, penderitaan batin Kartini Kartono. (2017:132). Konflik karyawan menjadi hal yang umum dijumpai yang bergelut dengan persoalan karyawan di perusahaan. Mulai dari atasan yang mengeluh tentang kinerja bawahannya, seorang karyawan yang bermasalah dengan karyawan lainnya, karyawan yang kerjanya tidak optimal karena masalah personal. Beberapa permasalahan tersebut mungkin terdengar 
sederhana, namun bagaimana mengatasi adanya konflik kerja tersebut menjadi tantangan tersendiri tentunya akan memengaruhi produktivitas kerja karyawan. Dengan demikian konflik adalah silang pendapat antara individu atau kelompok dengan tujuan dan persepsi yang berbeda.

Menurut Timpe (2017:204) produktivitas merupakan suatu konsep yang menunjukan adanya kaitan antara hasil kerja dengan satuan waktu yang dibutuhkan untuk menghasilkan produk seorang tenaga kerja. Seseorang dengan keleluasaan yang dimiliki akan berusaha untuk mencapai hasil kerja yang tinggi yang dilakukan dalam waktu yang telah ditentukan. Capaian pekerjaan dengan tepat waktu akan lebih efisien dengan dan dapat diprediksi tindakan atau pekerjaan yang akan dilakukan dikemudian hari sehinga semakin produktif. Produktifitas adalah kemampuan seseorang dalam menyelesaikan perkerjaan yang terukur untuk mencapai tujuan.

\section{KERANGKA PEMIKIRAN}

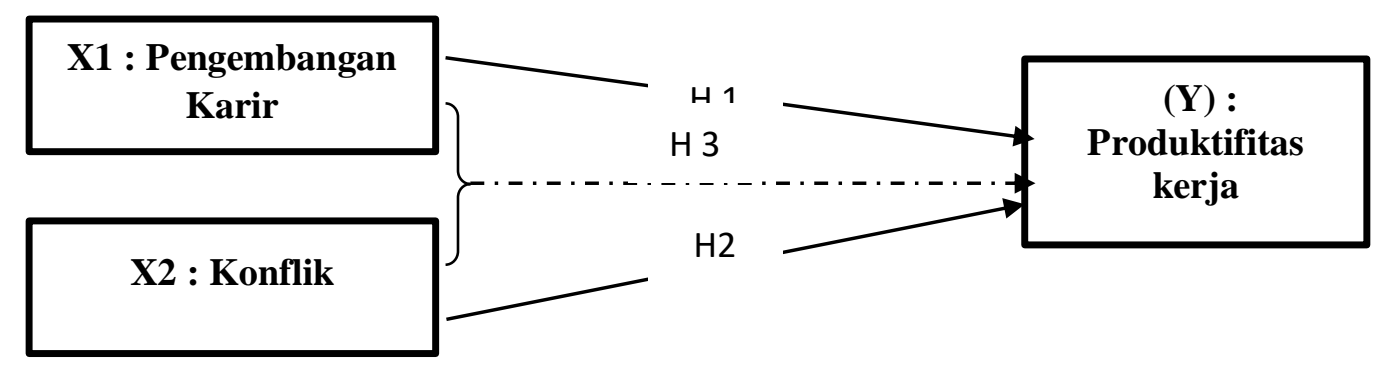

\section{HIPOTESIS}

H1 : Pengembangan Karir Berpengaruh Secara Parsial Terhadap Produktifitas Kerja Pada Badan Pengelola Keuangan, Pendapatan dan Aset Daerah Kabupaten Karo.

H2 : Konflik Berpengaruh Secara Parsial Terhadap Produktifitas Kerja Pada Badan Pengelola Keuangan, Pendapatan dan Aset Daerah Kabupaten Karo.

H3 : Pengembangan Karir dan Konflik Berpengaruh Secara Simultan Terhadap Produktifitas Kerja Pada Badan Pengelola Keuangan, Pendapatan dan Aset Daerah Kabupaten Karo.

\section{METODOLOGI PENELITIAN}

\section{POPULASI}

Dalam penelitian ini jumlah populasi adalah semua pegawai Badan Pengelola Keuangan, Pendapatan dan Aset Daerah Kabupaten Karo sebanyak 41orang karena layak dan mempunyai kesempatan yang sama untuk dijadikan populasi.

\section{JENIS DATA}

Jenis data yang digunakan dalam penelitian ini adalah data kuantitif dan kualitatif dengan pemberian skor yang diisi oleh para responden. 


\section{METODE ANALISA DATA}

\section{A. Uji Asumsi Klasik}

Uji asumsi klasik dilakukan dengan tujuan apakah hasil estimasi regresi terbebas dari bias yang mengakibatkan data tidak valid sehingga regresi tidak dapat digunakan untuk uji hipotesis dan penarikan kesimpulan. Uji asumsi klasik digunakan untuk memastikan bahwa data terdistribusi normal.(Manurung (2005:48).

\section{Normalitas}

Untuk memastikan terdistribusi normal atau tidak sebuah penelitian digunakan uji normalitas pada One Sample Kolmogrov Smirnov pada taraf signifikansi 0,05. Menurut Priyatno (2015:26) sebuah penelititan dikatakan terdistribusi normal terjadi jika signifikansi diatas 0,05 .

\section{Multikolinieritas}

Uji Multikolinieritas bertujuan untuk menguji regresi linier pada korelasi antar variabel bebas. Model regresi linier yang baik jika tidak ada korelasi pada variabel independen. Jika diantara variabel bebas saling berkorelasi maka variabel ini tidak ortogonal yaitu korelasi variabel bebas adalah nol. Dalam penelitian ini ada tidaknya multikolinieritas ditunjukkan nilai Variance Inflaction Factor (VIF) tidak lebih dari 10 dan nilai tolerance mendekati 1.

\section{Heteroskedastitas}

Uji heteroskedastisitas bertujuan untuk mengetahui apakah ketidaksamaan varians dari residu untuk semua pengamatan dalam model regresi linier. Persyaratan yang harus dipenuhi dalam model regresi linier adalah gejala heteroskedastisitas yang dilakukan melalui pengamatan grafik scatterplot model dengan pola titik yang menyebar diatas dan dibawah sumbu Y.

\section{B. REGRESI LINIER BERGANDA}

Teknik analisis yang digunakan daam penelitian ini adalah dengan menggunakan persamaan regresi liniear berganda dengan kriteria satu variabel dependen dan dua variabel independen. Sesuai dengan judul Pengaruh Pengembangan Karir dan Konflik Terhadap Produktifitas Kerja Pada Badan Pengelola Keuangan, Pendapatan dan Aset Daerah Kabupaten Karo. Menurut Sugiyono, (2016:277), mengemukakan rumus persamaan regresi linier berganda sebagai berikut:

$$
\begin{aligned}
& \mathrm{Y}=\mathrm{a}+\mathrm{b}_{1} \mathrm{X}_{1}+\mathrm{b}_{2} \mathrm{X}_{2}+\mathrm{e} \\
& \text { Keterangan: } \\
& \mathrm{Y}=\text { Produktifitas kerja } \\
& \mathrm{X}_{1}=\text { Pengembangan karir } \\
& \mathrm{X}_{2}=\text { Konflik } \\
& \mathrm{bi}=\text { Koefisien } \\
& \mathrm{a}=\text { Konstanta } \\
& \mathrm{e} \quad=\text { Error }
\end{aligned}
$$

\section{UJI HIPOTESIS}

\section{Uji - t (Uji Parsial)}

$\mathrm{Uji}$ - $\mathrm{t}$ bertujuan melihat secara parsial hubungan variabel bebas terhadap variabel terikat yaitu variabel $\mathrm{X} 1$ adalahpengembangan karir, $\mathrm{X} 2$ adalahkonflikterhadap $\mathrm{Y}$ yaituproduktifitas kerjasecara terpisah atau parsial. Bentuk pengujian adalah : 
Jika $\mathrm{t}$ tabel $>\mathrm{t}$ hitung maka Ho diterima dan Ha tolak. Jika $\mathrm{t}$ tabel $<\mathrm{t}$ hitung maka Ho diterima dan Ha terima. Jika angka signifikansi probabilitas $>0,05$ maka Ho terima dan Ha tolak. Jika angka signifikansi probabilitas $<0,05$ maka Ho terima dan Ha terima.

\section{Uji - F (Uji Simultan)}

Uji - F bertujuan melihat secara bersama (simultan) hubungan variabel bebas terhadap variabel terikat yaitu variabel $\mathrm{X}_{1}$ (pengembangan karir) dan $\mathrm{X}_{2}$ (konflik) sama-sama mempengaruhi $\mathrm{Y}$ (produktifitas kerja) dan membandingkan probabilitas ( $\mathrm{p}$ value) dengan taraf signifikan $5 \%$.

\section{Koefisien Determinasi $\left(\mathbf{R}^{2}\right)$}

Uji determinasi bertujuan menentukan persentase total variasi pada variabel terikat yang diterangkan oleh variabel bebas dengan menggunakan Adjusted $\mathrm{R}$ Square. Koefisien determinan $\left(R^{2}\right)$ menerangkan variasi variabel independen. Nilai koefisien determinan yang baik harus mendekati satu bukan mendekati nol.

\section{HASIL PENELITIAN}

\section{A. ASUMSI KLASIK}

\section{UJI NORMALITAS}

Uji normalitas digunakan dengan menggunakan uji Kilmogorov Smirnov dengan hasil sebagai berikut.

Tabel 1 Uji Normalitas

\begin{tabular}{|ll|r|}
\hline \multicolumn{2}{|c|}{ One-Sample Kolmogorov-Smirnov Test } \\
\hline & & \multicolumn{1}{|c|}{ Unstandardized Residual } \\
\hline $\mathrm{N}$ & & 41 \\
Normal Parameters $^{\mathrm{a}}$ & Mean & .0000000 \\
& Std. Deviation & .91874558 \\
Most Extreme Differences & Absolute & .076 \\
& Positive & .056 \\
& Negative & -.076 \\
Kolmogorov-Smirnov Z & & .485 \\
Asymp. Sig. (2-tailed) & & .973 \\
\hline a. Test distribution is Normal. & & \\
\hline
\end{tabular}

Berdasarkan tabel 1 terlihat bahwa nilai asymp. Sig (2-tailed) adalah 0.973 dan lebih besar dari sig- $\alpha(0,05)$. Artinya memenuhi syarat uji normalitas yaitu nilai sig- $p>\operatorname{sig}-\alpha(0,05)$, sehingga dapat dikatakan bahwa data penelitian berdistribusi secara normal.

\section{Uji Multikolinearitas}

Uji multikolinearitas bertujuan untuk menguji apakah model regresi ditemukan adanya kolerasi antar variabel bebas (independen).

\section{Tabel 2 Uji Mutikolinearitas}

\begin{tabular}{|cl|r|r|}
\hline \multirow{2}{*}{ Model } & \multicolumn{2}{|c|}{ Collinearity Statistics } \\
\cline { 3 - 4 } & & Tolerance & \multicolumn{1}{|c|}{ VIF } \\
\hline \multirow{2}{*}{1} & (Constant) & .702 & \\
& Pengembangan Karir & .702 & 1.425 \\
& Konflik & 1.425 \\
\hline
\end{tabular}

a. Dependent Variable: Produktifitas Kerja 
Tabel 2 diatas terlihat bahwa nilai tolerace variabel $\left(\mathrm{X}_{1}\right)$ dan $\left(\mathrm{X}_{2}\right)$ adalah 0,702 lebih besar dari 0.10 dan nilai VIF variabel $\left(\mathrm{X}_{1}\right)$ dan $\left(\mathrm{X}_{2}\right)$ adalah 1,425 lebih kecil dari 10 sehingga memenuhi persyaratan uji multikolinearitas yaitu jika nilai tolerance $>0,10$ dan nilai VIF $<10$, maka dapat disimpulkan bahwa variabel $\left(\mathrm{X}_{1}\right)$ dan $\left(\mathrm{X}_{2}\right)$ tidak mengandung gejala mutikolinearitas.

\section{Uji Heteroskedastisitas}

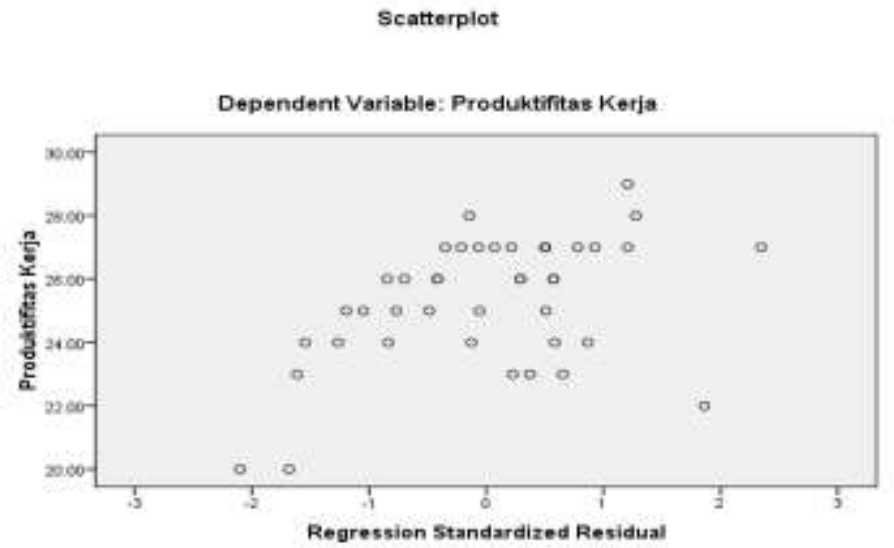

Hasil pengujian heteroskedastisitas menunjukkan bahwa titik-titik yang tidak membentuk pola tertentu atau tidak ada pola yang jelas serta titik-titik menyebar di atas dan dibawah angka 0 (nol) pada sumbu Y, maka tidak terjadi heteroskedastisitas.

\section{B. ANALISIS REGRESI LINEAR BERGANDA}

Perhitungan statistik dalam analisis regresi linear berganda yang digunakan dalam penelitian ini adalah dengan menggunakan bantuan program komputer SPSS.

Tabel 3 Regresi Linier Berganda

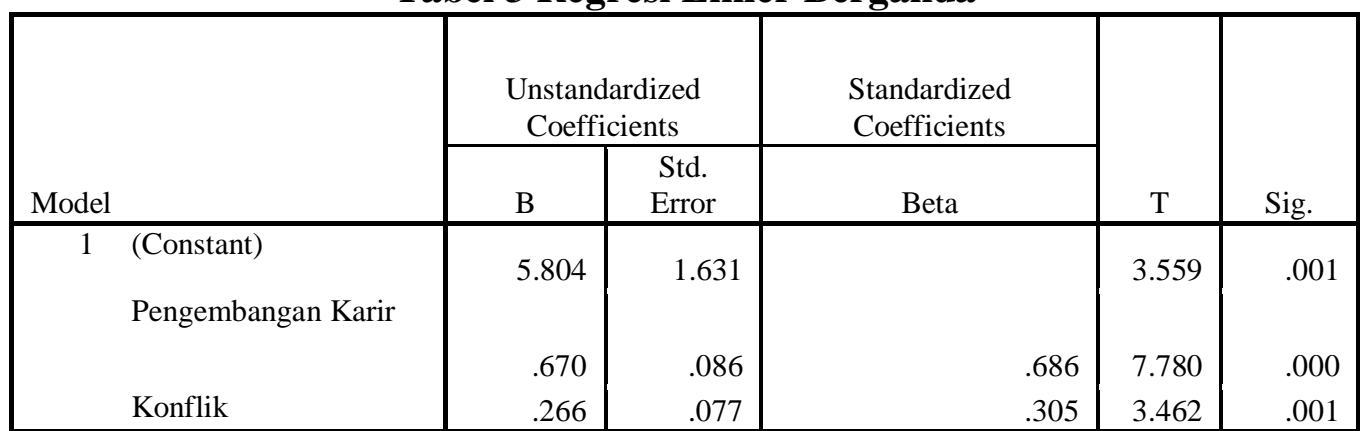

a. Dependent Variable: Produktifitas Kerja

Dari hasil tersebut diatas, apabila ditulis dalam bentuk persamaan regresinya adalah sebagai berikut :

$$
Y=5.804+0,670 X_{1}+0,266 X_{2}
$$

Persamaan analisis regresi linear berganda ini dapat diartikan sebagai berikut:

1. Nilai konstanta 5,804, artinya produktifitas kerja sebesar 5,804jikapengembangan karir dan konflik jika dimasukkan dalam persamaan. 
2. Nilai koefisien regresi pengembangan karir $\left(X_{1}\right)$ sebesar 0,670 artinya jika pengembangan karir naik satu satuan dan variabel lainnya tetap maka produktifitas kerja akan naik sebesar 0,670.

3. Nilai koefisien regresi konflik $\left(\mathrm{X}_{2}\right)$ sebesar 0,266 artinya jika konflik naik satu satuan dan variabel lainnya tetap maka produktifitas kerja akan naik sebesar 0,266.

\section{HIPOTESIS}

\section{Uji - t (Uji Parsial)}

Hasil uji-t dapat dilihat pada tabel regresi.

a. Variabel Pengembangan Karir

Hasil pengujian dengan SPSS diperoleh untuk variabel $\mathrm{X}_{1}$ (pengembangan karir) diperoleh nilai $t_{\text {hitung }}=7,780$ dengan nilai $t_{\text {tabel }}$ sebesar 1,682 maka keputusan menerima $\mathrm{Ha}$ dan menolak Ho karena $t_{\text {hitung }}$ lebih besar dari $t_{\text {tabel. }}$.

b. Variabel Konflik

Hasil pengujian SPSS diperoleh variabel $X_{2}$ (konflik) diperoleh nilai $t_{\text {hitung }}$ sebesar 3,462 dengan nilai $\mathrm{t}_{\text {tabel }}=1,682$ maka menerima Ha dan menolak Ho karena nilai $t_{\text {hitung }}$ lebih besar dari $t_{\text {tabel }}$.

\section{Uji-F (Simultan)}

Uji $\mathrm{F}$ digunakan untuk menentukan hasil perhitungan parameter model regresi secara bersama-sama (simultan). Dari hasil perhitungan yang diperoleh pada tabel berikut ini :

Tabel 4 Uji-F (Simultan)

\begin{tabular}{|c|c|c|c|c|c|c|}
\hline \multicolumn{2}{|l|}{ Model } & $\begin{array}{c}\text { Sum of } \\
\text { Squares }\end{array}$ & Df & $\begin{array}{l}\text { Mean } \\
\text { Square }\end{array}$ & $\mathrm{F}$ & Sig. \\
\hline & Regression & 129.114 & 2 & 64.557 & 72.657 & $.000^{\mathrm{a}}$ \\
\hline & Residual & 33.764 & 38 & .889 & & \\
\hline & Total & 162.878 & 40 & & & \\
\hline
\end{tabular}

a. Predictors: (Constant), Konflik, Pengembangan Karir

b. Dependent Variable: Produktifitas Kerja

Hasil perhitungan statistik menunjukkan nilai $F_{\text {hitung }}$ sebesar 72,657 dengan nilai $F_{\text {tabel }}=3,23$ dan nilai signifikansi sebesar 0,000 . Hal ini berarti bahwa secara bersama-sama pengembangan karir dan konflik mempunyai pengaruh yang signifikan terhadap produktifitas kerja atau Ha diterima dan Ho ditolak.

\section{Uji Koefisien Determinasi $\left(\mathbf{R}^{2}\right)$}

Berdasarkan hasil pengolahan data dengan program SPSS, maka diperoleh hasil sebagai berikut. 
Tabel 5 Hasil Uji Koefisien Determinasi $\mathbf{R}^{2}$

\begin{tabular}{|c|c|c|c|c|c|c|c|c|c|}
\hline & \multirow[b]{2}{*}{$\mathrm{R}$} & \multirow[b]{2}{*}{$\begin{array}{c}\mathrm{R} \\
\text { Square }\end{array}$} & \multirow[b]{2}{*}{$\begin{array}{c}\text { Adjusted } \\
\text { R } \\
\text { Square }\end{array}$} & \multirow{2}{*}{$\begin{array}{l}\text { Std. } \\
\text { Error of } \\
\text { the } \\
\text { Estimate }\end{array}$} & \multicolumn{5}{|c|}{ Change Statistics } \\
\hline & & & & & $\begin{array}{c}\text { R } \\
\text { Square } \\
\text { Change }\end{array}$ & $\begin{array}{c}\mathrm{F} \\
\text { Change }\end{array}$ & df1 & $\mathrm{df} 2$ & $\begin{array}{l}\text { Sig. F } \\
\text { Change }\end{array}$ \\
\hline & $\overline{890}$ & .793 & .782 & .94261 & .793 & 72.657 & & 3 & .000 \\
\hline
\end{tabular}

a. Predictors: (Constant), Konflik, Pengembangan Karir

Hasil perhitungan diketahui bahwa koefisien determinasi (adjusted $R^{2}$ ) yang diperoleh sebesar 0,782 . Artinya besaran pengaruh variabel pengembangan karir dan konflik terhadap produktifitas kerja sebesar 78,2\%, sedangkan sisanya yaitu $21,8 \%$ produktifitas kerja dipengaruhi oleh variabel-variabel lainnya yang diteliti dalam penelitian ini, misalnya disiplin kerja, pelatihan dan lain lain.

\section{KESIMPULAN}

Berdasarkan hasil peneletian dan kajian yang tela diuraikan sebelumnya, maka dapat disimpulkan menjadi beberapa hal sebagai berikut :

1. Variabel pengembangan karir $\left(\mathrm{X}_{1}\right)$ berpengaruh positif dan signifikan terhadap produktifitas kerja $(\mathrm{Y})$ dengan nilai $\mathrm{t}_{\text {hitung }}=7,780$ dengan nilai $\mathrm{t}_{\text {tabel }}$ sebesar 1,682 .

2. Variabel konflik $\left(\mathrm{X}_{2}\right)$ memiliki pengaruh positif dan signifikan terhadap produktifitas kerja $(\mathrm{Y})$ dengan nilai $\mathrm{t}_{\text {hitung }}=3,462$ dengan nilai $\mathrm{t}_{\text {tabel }}$ sebesar 1,682 .

3. Variabel pengembangan karir $\left(\mathrm{X}_{1}\right)$ dan konflik $\left(\mathrm{X}_{2}\right)$ secara bersamaan memiliki pengaruh positif dan signifikan terhadap produktifitas kerja (Y) yang ditunjukkan oleh nilai $F_{\text {hitung }}$ sebesar 72,657 dengan nilai $F_{\text {tabel }}=3,23$ dan nilai signifikansi sebesar 0,000 .

\section{DAFTARPUSTAKA}

Anoraga, Pandji. (2015). Manajemen Bisnis. Jakarta: Rineka Cipta.

Augusty, Ferdinand. (2016). Metode Penelitian Manajemen. Semarang: Badan Penerbit Universitas Diponegoro.

Ahmad Tohardi. (2017). Pemahaman Praktis Manajemen Sumber Daya Manusia, Mandar Maju. Bandung.

Arep dan Tanjung. (2018). Manajemen Sumber Daya Manusia. Edisi Kedua. Yogyakarta : BPEC.

Dale, Timpe. (2017). Seri Manajemen Sumber Daya Manusia Kinerja, cetakan kelima, Jakarta : PT Elex Media Komputindo.

Fathoni, Adburrahman. (2016). Organisasi dan Manajemen Sumber Daya Manusia. Jakarta: Rineka Cipta.

Ghozali, Imam. (2016). Aplikasi Analisis Multivariate Dengan Program SPSS. Semarang : Badan Penerbit Diponegoro

Gulo, W. (2015). Metodologi Penelitian. Jakarta: PT. Grasindo 
Hasibuan, Malayu S.P. (2015). Manajemen Sumber Daya Manusia. Jakarta: PT Bumi Aksara

Henry Simamora. (2016). Manajemen Sumber Daya Manusia. Yogyakarta: BPSTIEYKPN

John Suprihanto dan Djati Julitriarsa. (2016). Manajemen Umum, Sebuah Penghantar. Edisi Pertama. Cetakan Ketiga. Yogyakarta: BPFE

Kartini Kartono. (2017). Pemimpin dan Kepemimpinan. Jakartaaa: PT. Grafindo Persada.

Mangkunegara Anwar Prabu. (2017). Evaluasi Kinerja Karyawan SDM, Cetakan Kelima. Jakarta: Refika Aditama.

Manurung, Jonni. (2005). Ekonometrika: Teknik Pemodelan Dasar dan Lanjutan. Cetakan Pertama, Jakarta: PT Alex Media Komputindo.

Martono, Nanang. (2016). Metode Penelitian Kuantitatif. Jakarta: PT. Rajagrafindo Persada.

M Kadarisman (2017). Manajemen Kompensasi. Jakarta : Rajagrafindo Persada.

Nasution, Mulia. (2016). Manajemen Personalia. Jakarta: Djambatan.

Priyatno, Duwi. (2010). Analisa Statistik Data dengan SPSS. Yogyakarta: Media Kom.

Ranupandojo, H., dan Suad Husnan. (2016). Manajemen Personalia. Yogyakarta: BPFE

Samsudin, Sadili. (2017). Manajemen Sumber Daya Manusia. Cetakan Kesatu. Bandung: Pustaka Setia.

Sedarmayanti. (2015). Sumber Daya Manusia dan Produktivitas Kerja. Bandung: Mandar Maju.

Siagian, Sodang P. (2015). Manajemen Sumber Daya Manusia. Jakarta: Bumi Aksara.

Siregar, Sofian. (2016). Metode Penelitian Kuantitatif. Jakarta: Kencana Prenada Media Group.

Sugiyono. (2016). Metode Penelitian Kuantitatif, Kualitatif, dan $R$ dan $D$. Cetakan Ke- 17. Bandung: Alfabeta.

Sunyoto, Danang. (2017). Teori, Kuesioner, dan Analisis Data Sumber Daya Manusia Cetakan ke-2. Yogyakarta: CAPS.

Sutrisno, Edy. (2015). Manajemen Sumber Daya Manusia. Edisi 1. Cetakan Kedua. Jakarta: Prenada Media Group.

Wursanto, IG. (2016). Manajemen Kepegawaian. Yogyakarta: Penerbit Kanisius. 